\title{
Relations that Show the Network Potential for Spatial Data Sharing
}

\author{
Fatih TAKTAK, Hulya DEMIR
}

\begin{abstract}
Physical and functional cooperation based on a certain hierarchy among public institutions, local governments, private sectors and all other industries that work with spatial data is a very important dynamic. This cooperation between organizations or individuals is actually built with unofficial networks that are not bound by predefined rules. By utilizing network analysis, a formal presentation of the existing collaborations and communication networks can be made.The questions that were asked to organizations during the research were selected to determine various issues such as their collaborations within the network, data exchange potential and awareness to understand the direction of the flow. This study provided an insight into the organizations that should be prioritized in any regulation and initiative on the spatial data infrastructure (SDI). Furthermore, it is proposed that organizations that are currently less active with spatial data can play a more active role with the quantitative and qualitative increase in e-applications.
\end{abstract}

Keywords: interoperability; SDI; social network analysis; spatial data exchange

\section{INTRODUCTION}

Spatial data, which can be defined as data that have a spatial component, i.e. the data that are connected to a place in the Earth, have an economical value as an important component of public information [1, 2]. Additionally, it provides a basis for country politics and decision-making mechanisms and has a social importance due to its tangible benefits for public institutions and bodies and for the private sector [3,4]. Decision making processes based on geographic information in projects can be performed with integrity using Geographic Information Systems (GIS) [5, 6]. However today coordinated generation, update, sharing and use of local/regional/ national and international level information has become an important necessity [7-9]. Spatial data and services are shared and integrated to use Spatial Data in decision making process to provide efficient services to citizens [10].

INSPIRE is an initiative started by the European Commission and developed with the cooperation of member states and participating countries. The European Union requires that spatial data should be provided efficiently to manage environmental issues and to develop environmental policies. Therefore, the European Commission started INSPIRE to develop, implement and monitor environmental policies [11, 12].

It is a system which enables both vertical and horizontal effective data sharing, instant access and use of services and interoperability that all public institutions and bodies, local governments, private sector and all other sectors working with spatial data need $[13,14]$. It is a comprehensive system which is built to allow fast, costefficient and effective access to data which organizations require to carry out their activities [15]. Technological tools based on spatial data have been increasing and the number of users has also been increasing parallel to that [16].

To achieve data exchange between organizations, operational, physical and hierarchical boundaries of the organizations should be determined and an effective cooperation should be established. The system that will reveal the invisible cooperation between organizations is a social network [17, 18]. Social Network Analysis (SNA) can be defined as the digitalization of relations between actors used to convert existing intra-organizational or inter- organizational relations into digital data. As the form and shape of the network obtained with the digitalized data shows the efficiency of the intra-organizational or interorganizational communication network, it provides guidance to take necessary measures or provide support for the subject analysed [19].

Their interoperability structure for spatial purposes is CBS. Interoperability in INSPIRE means the possibility to combine spatial data and services from different sources across the European Community in a consistent way without involving specific efforts of humans or machines. This definition does not focus on how systems interact but rather on the integration of the existing data obtained from different sources after the barriers that the system users frequently encounter are eliminated [20].

\section{INTERNATIONAL STANDARD INSPIRE}

The European Union (EU) member states are working to integrate in technical areas in addition to economic, social and cultural areas. The member states have realized the importance of having one single structure of spatial data under the EU and therefore started an important initiative. For this purpose, the European Parliament approved the directives on the infrastructure for spatial information and published in the Official Journal of the European Union and came into force on May 15, 2007. Thus the framework directives for the Infrastructure for spatial information in Europe (INSPIRE) have become something to act on [21].

The main objective of INSPIRE is to ensure spatial data sharing between member countries to develop, evaluate, monitor and implement EU policies, and ensure easy access to spatial data on environmental, agricultural, transport and other areas for citizens and business environment at the local, regional, national and international levels by providing high quality access to spatial data [22].

\section{INFRASTRUCTURE FOR SPATIAL DATA}

There are many national and international projects to build infrastructures for spatial data. INSPIRE initiated under the control of the Environment Directorate-General of the European Commission is an European Union (EU) 
initiative which will provide coordination for the management of spatial information long Europe. The INSPIRE project develops technical standards, protocols to generate spatial data, to allow access and use of such data and regulations on public coordination and spatial data and acts as guidelines for any work on geographic data infrastructure of the European countries. This initiative aims to provide consistent, high quality, accessible and shareable information to support European policies on environment, agriculture, healthcare, transport and many other industries at local, regional and national levels [23].

When building of a SDI, existing positions of local and international organizational stakeholders should be determined. The potential of the stakeholders that generate and use spatial data to manage spatial data; hardware, software and electronic network infrastructure; regulations on data transfer/share process and employees' ability to use data are critical [24].

All industries that use spatial data such as public institutions and agencies, local governments, and private enterprises access the data they need and share the data they have via the services that allow "interoperability" in the SDI. Work on systems and software architecture that ensures the interoperability of applications that use different programming language, located in different locations on the network and work on computers with different hardware to perform the required tasks continues [25].

Pragmatic interoperability; interconnected systems understand each other. Thus they can use applications / service interfaces, retrieve methods and procedures and exchange the data they process with other systems. The most important feature of this interoperability is that it makes it possible for the systems to communicate or interact. Perfectly defined service interfaces are required to achieve this level of interoperability. At the same time, methods that recall data are required. The mechanisms that support interoperability are standards and practices including ISO standard 19128 (web Map Server Interface), ISO 19142 and OGC service interfaces [26].

\section{SOCIAL NETWORK ANALYSIS}

A social network consists of people who are referred to as actors and the connections between these people. SNA can be defined as the conceptualization of structures arising from the relations between these actors into mathematical format and then analysis of these relations using certain methods [27].

Actors are connected to each other in many networks in which each connection/tie represents a network in the complex structure of social relations. These complex relation structures are analysed by an analysis tool called Social Network Analysis. A social network analysis allows us to see the things that are not possible to be seen with the naked eye. The main objective of a social network analysis is to define and interpret paths of social ties [28]. SNA aims to understand the network structure by identification, visualization and modelling [29]. In a geometric plane, each unit is shown with a node (vertice) and the connections between nodes are shown with arrows or lines [30].

\subsection{Social Network Analysis Measures}

Based on the assumption of the importance of the relation between interacting groups, SNA is the analysis of all kinds of relations/ties between the actors i.e. organizations, individuals or groups that are shown as nodes on the lines. A SNA aims to make assumptions and generate data about an individual or group by examining the structure of a social network.

In order to conduct a SNA, certain data that explains which actor has ties with which actor must be available. Mathematical measurement and calculation methods used to define and analyse the social network mechanism after the network relation data has been entered are different from the statistical methods used for data analysis of any quantitative research in social sciences. Certain measurement methods are used to explain the positions of actors in the network and to define the network mechanism as a whole in the analysis of a social network mechanism. In Tab. 1 the definitions of the measures that are important to show the hierarchical structure of a network mechanism, to determine power relations and to identify communication methods are shown. Tab. 2 shows the definition of the task measures of the actors in the network [31].

Table 1 Social network mechanism measures used for actors

\begin{tabular}{|c|c|}
\hline Measure & Definition \\
\hline Degree & Number of direct connections to other actors [32]. \\
\hline Indegree & $\begin{array}{l}\text { Number of connections of other elements to the actor } \\
\text { (receiving connections). }\end{array}$ \\
\hline Outdegree & $\begin{array}{l}\text { Number of connections of the actor to other elements } \\
\text { (sending connections). }\end{array}$ \\
\hline Closeness & $\begin{array}{l}\text { The closeness of an actor to other actors within the } \\
\text { network or the degree of accessibility. It is generally } \\
\text { calculated by averaging an actor's path distance (direct } \\
\text { or indirect connections) to all others. While a direct } \\
\text { relation is valued at } 1 \text {, indirect relations are valued at a } \\
\text { lower number proportionately [33]. }\end{array}$ \\
\hline Betweenness & $\begin{array}{l}\text { It is the degree of an actor's preference to be or } \\
\text { intermediate between two actors which are closest to } \\
\text { each in the network mechanism. It is generally } \\
\text { calculated according to the average of all possible } \\
\text { bilateral relations in the network [34]. }\end{array}$ \\
\hline Centrality & $\begin{array}{l}\text { It is the measure of an actor's degree of being positioned } \\
\text { in the centre in the network mechanism. The measures } \\
\text { of degree, closeness, and betweenness are generally } \\
\text { used as the determinants of the centrality. Some } \\
\text { centrality measures weight an actor's relation with } \\
\text { others by using others' degree of centrality. }\end{array}$ \\
\hline Density & $\begin{array}{l}\text { The ration between current connections and possible } \\
\text { connections in the network mechanism [35]. }\end{array}$ \\
\hline
\end{tabular}

Table 2 Actors' roles in the network

\begin{tabular}{|c|l|}
\hline Measure & \multicolumn{1}{c|}{ Definition } \\
\hline Star & An actor with a high centrality in the network. \\
\hline Intermediary & $\begin{array}{l}\text { An actor which connects two or more groups which } \\
\text { would not have any relation otherwise. }\end{array}$ \\
\hline Bridge & An actor which is a member to two or more groups. \\
\hline Gatekeeper & $\begin{array}{l}\text { An actor that controls information flow over one single } \\
\text { connection between one and another section of the } \\
\text { network. }\end{array}$ \\
\hline Isolated & An actor who has none or very few ties with others. \\
\hline
\end{tabular}

\section{IMPLEMENTATION}

The cooperation of organizations that generate or use spatial data within a network was studied using the SNA method. NetMiner 4 software program, which is one of the 
SNA software programs that are preferred for scientific publications, was used for statistical and visual evaluations. In this study, 24 organizations in public and private sectors that used or generated spatial data were selected as the sample of the study (Tab. 3).

Table 3 Organizations to which survey questions were asked

\begin{tabular}{|l|c|}
\hline \multicolumn{1}{|c|}{ Name of Institution } & Abbreviation \\
\hline Usak Municipality & UM \\
\hline Special Provincial Administration & SPA \\
\hline State Hydraulic Works & SHW \\
\hline Housing Development Administration & HDA \\
\hline Forest Management Directorate & FMD \\
\hline The Directorate of Highways & DH \\
\hline Department of Environment and Urbanization & DEU \\
\hline Directorate of Title Deed Registry and Cadastre & DTDRC \\
\hline Foundations & F \\
\hline Turkish Electricity Distribution Company & TEDC \\
\hline Governorship & G \\
\hline Provincial Directorate of Agriculture & PDA \\
\hline Real Estate Agent & REA \\
\hline Banks & B \\
\hline National Real Estate Department & NRED \\
\hline Licensed Bureau of Surveying Engineering & LBSE \\
\hline Telecom Directorate & TD \\
\hline Directorate of Disaster Affairs & DDA \\
\hline Independent Survey and Cadastre Office & ISCO \\
\hline Chamber of Commerce & CC \\
\hline Chamber of Agriculture & CA \\
\hline Directorate of Museums & DM \\
\hline University of Usak & UU \\
\hline Courts & C \\
\hline
\end{tabular}

Likert scale was used in this study. Based on the recommendations, an odd-numbered scale was used. Additionally, the scale of $0-8$ was chosen to show the weight in the network figures clearly. As the study would have a network mechanism sample, sample was selected to be limited in space. The position-based approach was used to define the limits of samples [36]. In the position based approach, the presence of a membership relation for the network in which actors are in can be proved. The reason why limited space is used in the study is that the number of relations researched and compared increases exponentially with the number of volunteers. Therefore, studies in which sociometric data is collected and use a matrix approach usually have 40 or less samples [37].

Therefore, we can conclude the sample we used in this study is adequate for a sociometric research. All of the volunteers in the sample were engineers or people with a technical job.

\subsection{Relations Which Show the Network's Potential for Data Sharing}

The potential for spatial data sharing of the organizations which generate and use data is mostly examined using existing data and software tools for the present state evaluation during the INSPIRE process. However, it is important to evaluate all components of the potential for spatial data management to determine present state and requirements in organizations.

Table 4 Survey questions which show the network potential for data sharing

\begin{tabular}{|c|c|c|}
\hline No & Relations which show the network potential for data sharing & disagree $\longrightarrow$ agree \\
\hline 1 & Can you have access to the following organizations to collect data? & $\begin{array}{lllllllll}0 & 1 & 2 & 3 & 4 & 5 & 6 & 7 & 8\end{array}$ \\
\hline 2 & To what extent the organizations provide you the data you need? & $23 \quad 4 \quad 5$ \\
\hline 3 & To which organizations you provide the data you generate and how often do you provide? & 2344 \\
\hline 4 & Do you know what kind of spatial data the following organizations generate? & 234 \\
\hline 5 & How often did you get the spatial data you need from the organizations within the last year? & 234 \\
\hline
\end{tabular}

Survey Question 1: Each organization that generates or uses spatial data was asked the question "Can you have access to the following organizations to collect data?" and network and centrality graphs were created using the data obtained from the answers to this question. Actors and data access network among actors are shown in Fig. 1.

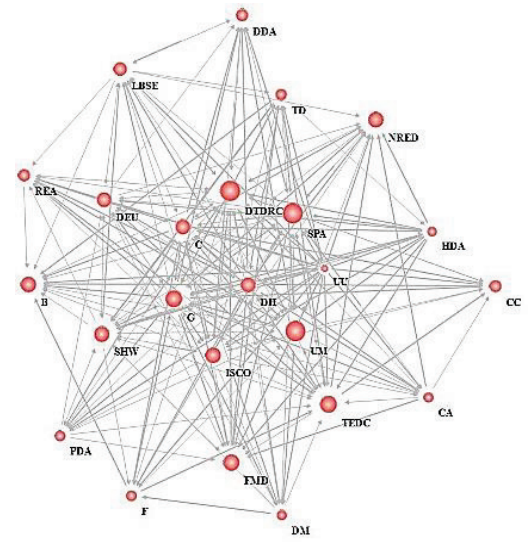

(a)

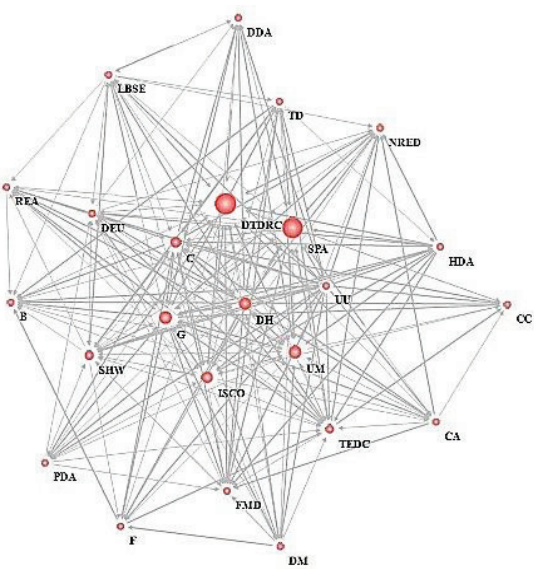

(b)

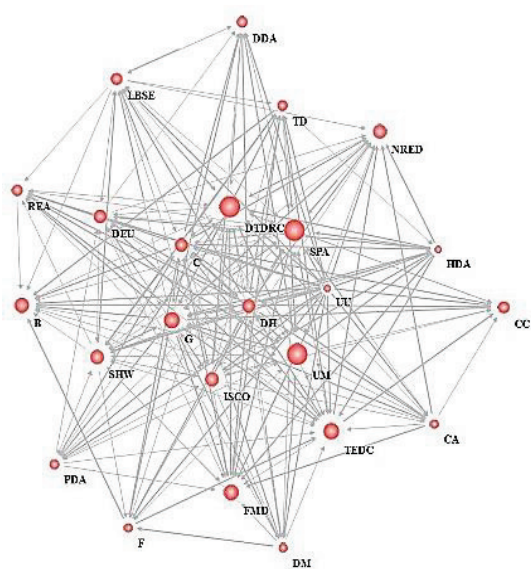

(c)

Figure 1 Based on the answers to the first questions, the following graphs for actors and ties between actors were created: (a) Degree network map and degree centrality graph; (b) Betweenness network map and betweenness centrality graph; (c) Closeness network map and closeness centrality graph

The survey questions in this study (Tab. 4) were developed based on the questions that aim to reveal important network relations included in the book "Hidden Power of Social Network". Based on the answers to the questions that show the network's potential for data sharing; network and centrality graphs which show important results on the organizations which generate data and whether the spatial data they generate is known; whether easy access to obtain from these organizations is possible, how often spatial data is obtained and to what extent the required data is provided and to which organization the generated data is provided were 
developed. 3 maximum and minimum standard deviations and 3 deviations in organizations were added in the graphs created with the values of centrality measures (Tab. 5).

Table 5 Maximum and minimum values for the in-out degree, betweenness and closeness centrality of the question, "Can you have access to the following organizations to collect data?"

\begin{tabular}{|c|c|c|c|c|c|}
\hline & & Maximum & & Minimum & Std. Dev. \\
\hline \multirow{3}{*}{ In Degree } & Usak Municipality & 0,870 & University of Usak & 0,087 & \multirow{3}{*}{0,197} \\
\hline & Special Provincial Administration & 0,870 & Housing Development Administration & 0,261 & \\
\hline & Directorate of Title Deed Registry and Cadastre & 0,870 & Directorate of Museums & 0,304 & \\
\hline \multirow{3}{*}{ Out Degree } & University of Usak & 1,000 & Chamber of Commerce & 0,000 & \multirow{3}{*}{0,323} \\
\hline & The Directorate of Highways & 1,000 & Banks & 0,000 & \\
\hline & Governorship & 0,957 & Forest Management Directorate & 0,043 & \\
\hline \multirow{3}{*}{ Betweenness } & Directorate of Title Deed Registry and Cadastre & 0,102 & Chamber of Commerce & 0,000 & \multirow{3}{*}{0,029} \\
\hline & Special Provincial Administration & 0,099 & Chamber of Agriculture & 0,000 & \\
\hline & Governorship & 0,045 & Directorate of Disaster Affairs & 0,000 & \\
\hline \multirow{3}{*}{ In Closeness } & Usak Municipality & 0,872 & University of Usak & 0,468 & \multirow{3}{*}{0,109} \\
\hline & Special Provincial Administration & 0,872 & Housing Development Administration & 0,479 & \\
\hline & Directorate of Title Deed Registry and Cadastre & 0,872 & Foundations & 0,548 & \\
\hline \multirow{3}{*}{$\begin{array}{c}\text { Out } \\
\text { Closeness }\end{array}$} & University of Usak & 1,000 & Chamber of Commerce & 0,000 & \multirow{3}{*}{0,256} \\
\hline & The Directorate of Highways & 1,000 & Banks & 0,000 & \\
\hline & Governorship & 0,958 & Forest Management Directorate & 0,479 & \\
\hline
\end{tabular}

Survey Question 2: Each organization that generates or uses spatial data was asked the question "To what extent do the organizations provide you the data you need?" and network and centrality graphs were created using the data obtained from the answers to this question. The overview of the network for actors and ties between actors is shown in Fig. 2 .

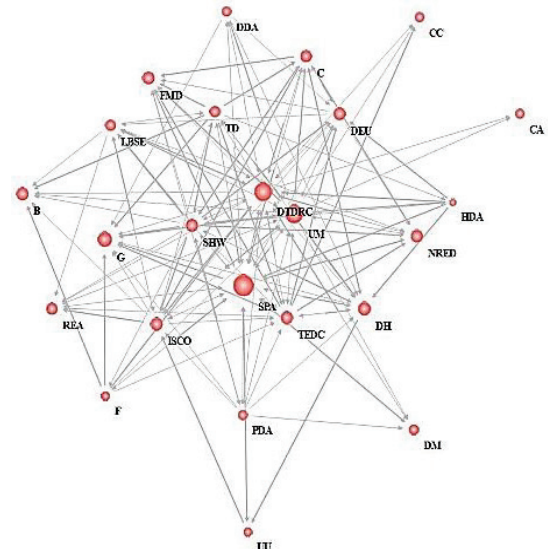

(a)

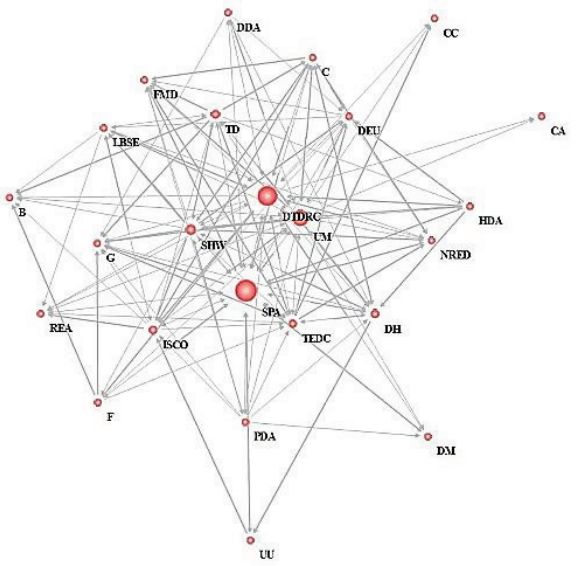

(b)

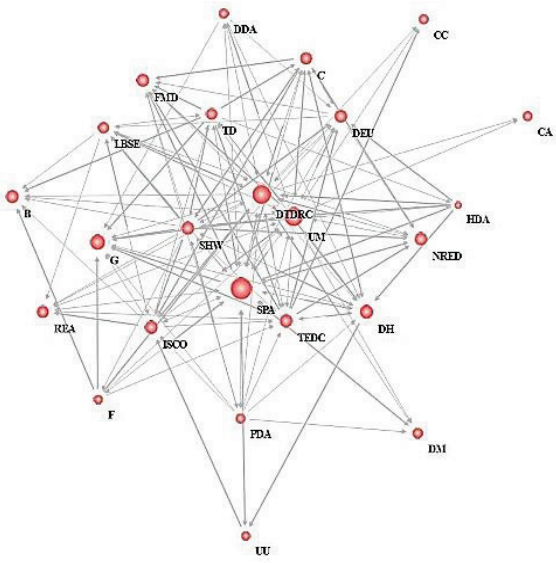

(c)

Figure 2 Based on the answers to the first questions, the following graphs for actors and ties between actors were created: (a) Degree network map and degree centrality graph; (b) Betweenness network map and betweenness centrality graph; (c) Closeness network map and closeness centrality graph

Table 6 Maximum and minimum values for the in-out degree, betweenness and closeness centrality of the question, "To what extent do the organizations provide you the data you need?"

\begin{tabular}{|c|c|c|c|c|c|}
\hline & & Maximum & & Minimum & Std. Dev. \\
\hline \multirow{3}{*}{ In Degree } & Special Provincial Administration & 0,783 & University of Usak & 0,087 & \multirow{3}{*}{0,194} \\
\hline & Directorate of Title Deed Registry and Cadastre & 0,696 & Chamber of Agriculture & 0,087 & \\
\hline & Usak Municipality & 0,696 & Foundations & 0,087 & \\
\hline \multirow{3}{*}{ Out Degree } & Directorate of Title Deed Registry and Cadastre & 0,870 & Governorship & 0,000 & \multirow{3}{*}{0,269} \\
\hline & Usak Municipality & 0,826 & Chamber of Agriculture & 0,000 & \\
\hline & Special Provincial Administration & 0,826 & Chamber of Commerce & 0,000 & \\
\hline \multirow{3}{*}{ Betweenness } & Special Provincial Administration & 0,181 & National Real Estate Department & 0,000 & \multirow{3}{*}{0,05} \\
\hline & Directorate of Title Deed Registry and Cadastre & 0,161 & Directorate of Disaster Affairs & 0,000 & \\
\hline & Usak Municipality & 0,115 & Forest Management Directorate & 0,000 & \\
\hline \multirow{3}{*}{ In Closeness } & Special Provincial Administration & 0,785 & Foundations & 0,424 & \multirow{3}{*}{0,097} \\
\hline & Directorate of Title Deed Registry and Cadastre & 0,713 & University of Usak & 0,424 & \\
\hline & Usak Municipality & 0,713 & Housing Development Administration & 0,349 & \\
\hline \multirow{3}{*}{ Out Closeness } & Directorate of Title Deed Registry and Cadastre & 0,885 & Governorship & 0,000 & \multirow{3}{*}{0,258} \\
\hline & Usak Municipality & 0,852 & Chamber of Agriculture & 0,000 & \\
\hline & Special Provincial Administration & 0,852 & Chamber of Commerce & 0,000 & \\
\hline
\end{tabular}

Survey Question 3: Each organization that generates or uses spatial data was asked the question "To which organizations do you provide the data you generate and how often do you provide?" and network and centrality graphs were created using the data obtained from the answers to this question. The overview of the network for actors and ties between actors is shown in Fig. 3. 


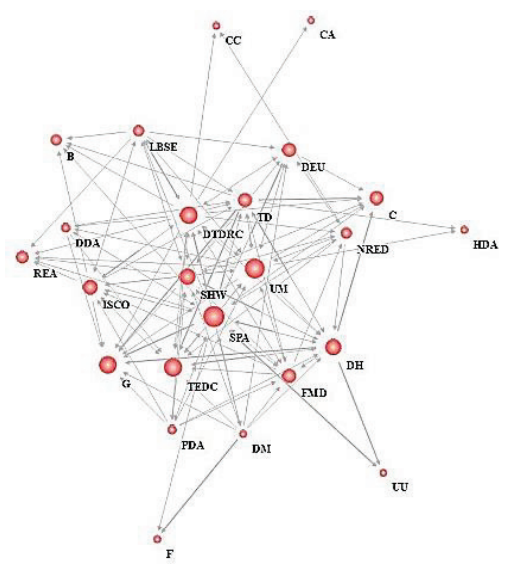

(a)

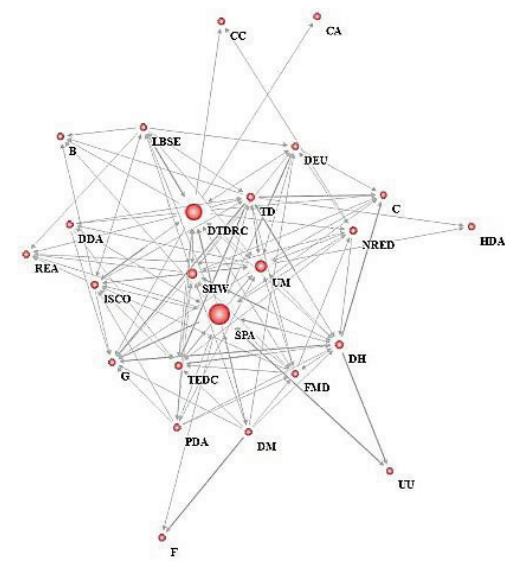

(b)

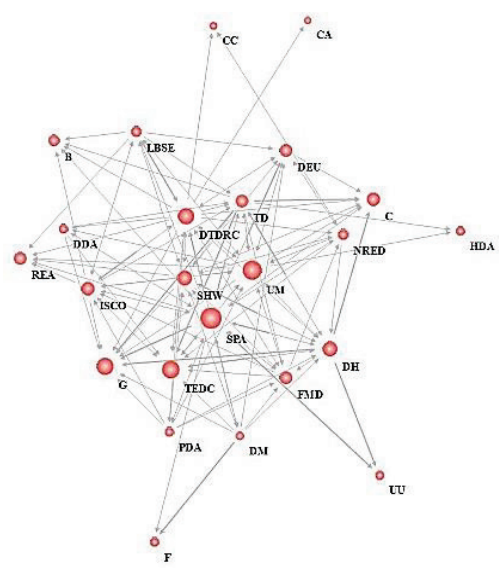

(c)

Figure 3 Based on the answers to the first questions, the following graphs for actors and ties between actors were created: (a) Degree network map and degree centrality graph; (b) Betweenness network map and betweenness centrality graph; (c) Closeness network map and closeness centrality graph

Table 7 Maximum and minimum values for the in-out degree, betweenness and in-out closeness centrality of the question "To which organizations do you provide the data you generate and how often do you provide them?"

\begin{tabular}{|c|c|c|c|c|c|}
\hline & & Maximum & & Minimum & Std. Dev. \\
\hline \multirow[t]{3}{*}{ In Degree } & Special Provincial Administration & 0,565 & Chamber of Agriculture & 0,043 & \multirow{3}{*}{0,152} \\
\hline & Usak Municipality & 0,522 & University of Usak & 0,087 & \\
\hline & TEDC & 0,478 & Directorate of Museums & 0,087 & \\
\hline \multirow[t]{3}{*}{ Out Degree } & Special Provincial Administration & 0,870 & University of Usak & 0,000 & \multirow{3}{*}{0,263} \\
\hline & Directorate of Title Deed Registry and Cadastre & 0,870 & Chamber of Agriculture & 0,000 & \\
\hline & State Hydraulic Works & 0,609 & Chamber of Commerce & 0,000 & \\
\hline \multirow[t]{3}{*}{ Betweenness } & Special Provincial Administration & 0,139 & University of Usak & 0,000 & \multirow{3}{*}{0,034} \\
\hline & Directorate of Title Deed Registry and Cadastre & 0,103 & Chamber of Agriculture & 0,000 & \\
\hline & Usak Municipality & 0,052 & Chamber of Commerce & 0,000 & \\
\hline \multirow[t]{3}{*}{ In Closeness } & Special Provincial Administration & 0,568 & Chamber of Agriculture & 0,296 & \multirow{3}{*}{0,07} \\
\hline & Usak Municipality & 0,533 & Chamber of Commerce & 0,316 & \\
\hline & Directorate of Title Deed Registry and Cadastre & 0,473 & Directorate of Museums & 0,328 & \\
\hline \multirow[t]{3}{*}{ Out Closeness } & Special Provincial Administration & 0,885 & University of Usak & 0,000 & \multirow{3}{*}{0,321} \\
\hline & Directorate of Title Deed Registry and Cadastre & 0,885 & Chamber of Agriculture & 0,000 & \\
\hline & State Hydraulic Works & 0,719 & Chamber of Commerce & 0,000 & \\
\hline
\end{tabular}

Survey Question 4: Each organization that generates or uses spatial data was asked the question "Do you know what kind of spatial data the following organizations generate? " and network and centrality graphs were created using the data obtained from the answers to this question. The overview of the network for actors and ties between actors is shown in Fig. 4.

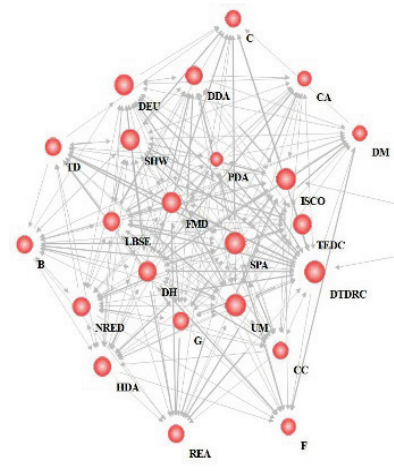

(a)

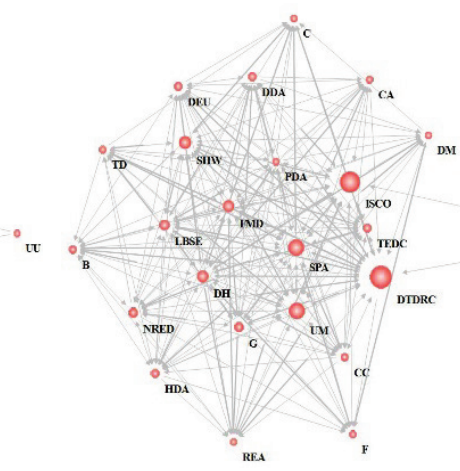

(b)

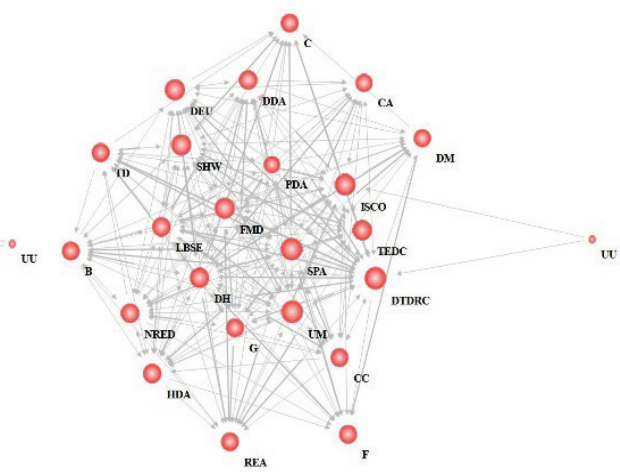

(c)

Figure 4 Based on the answers to the first questions, the following graphs for actors and ties between actors were created: (a) Degree network map and degree centrality graph; (b) Betweenness network map and betweenness centrality graph; (c) Closeness network map and closeness centrality graph

The first evaluation was made for density measures in order to analyze the complex structure of the network, and to make the network more understandable. The high density of number of ties between the nodes in a network means that the actors (organizations) either know each other or the number of interactions is high. The maximum number of ties for the network in the SDI performed for the twenty four organizations (n) in this study is $552(n(n-1))$. The calculations "General density of the network depending on the number of ties" in the chart 8 shows the percentage of potential ties that have been made.
When the relations that show the data sharing potential of the network were examined in Tab. 10, although the results to the questions on the knowledge of organizations about the data that the other organizations generate and mutual trust levels were above average, the access of organizations to other organizations to obtain data was found to be "moderate", frequency for obtaining information they need from other organizations within the last year, the extent of the data they provide to each other, the frequency at which they provide data to each other were found to be "low". 
Table 8 Maximum and minimum values for the in-out degree, betweenness and in-out closeness centrality of the question, "Do you know what kind of spatial data the following organizations generate?"

\begin{tabular}{|c|c|c|c|c|c|}
\hline & & Maximum & & Minimum & Std. Dev. \\
\hline \multirow[t]{3}{*}{ In Degree } & Usak Municipality & 0,870 & University of Usak & 0,000 & \multirow[t]{3}{*}{0,186} \\
\hline & Special Provincial Administration & 0,870 & Provincial Directorate of Agriculture & 0,391 & \\
\hline & Directorate of Title Deed Registry and Cadastre & 0,870 & Chamber of Agriculture & 0,478 & \\
\hline \multirow[t]{3}{*}{ Out Degree } & Usak Municipality & 0,957 & Courts & 0,000 & \multirow[t]{3}{*}{0,321} \\
\hline & Special Provincial Administration & 0,957 & Foundations & 0,000 & \\
\hline & The Directorate of Highways & 0,957 & Real Estate Agent & 0,261 & \\
\hline \multirow[t]{3}{*}{ Betweenness } & Directorate of Title Deed Registry and Cadastre & 0,047 & University of Usak & 0,000 & \multirow[t]{3}{*}{0,013} \\
\hline & Independent Survey and Cadastre Office & 0,043 & Chamber of Agriculture & 0,000 & \\
\hline & Special Provincial Administration & 0,029 & Courts & 0,000 & \\
\hline \multirow[t]{3}{*}{ In Closeness } & Usak Municipality & 0,872 & University of Usak & 0,000 & \multirow[t]{3}{*}{0,167} \\
\hline & Special Provincial Administration & 0,872 & Courts & 0,000 & \\
\hline & Directorate of Title Deed Registry and Cadastre & 0,872 & Foundations & 0,000 & \\
\hline \multirow[t]{3}{*}{ Out Closeness } & Usak Municipality & 0,957 & Courts & 0,000 & \multirow[t]{3}{*}{0,265} \\
\hline & Special Provincial Administration & 0,957 & Foundations & 0,000 & \\
\hline & Independent Survey and Cadastre Office & 0,957 & University of Usak & 0,523 & \\
\hline
\end{tabular}

Survey Question 5: Each organization that generates or uses spatial data was asked the question "How often do you get the spatial data you need from the organizations within the last year?" and network and centrality graphs were created using the data obtained from the answers to this question. The overview of the network for actors and ties between actors is shown in Fig. 5.
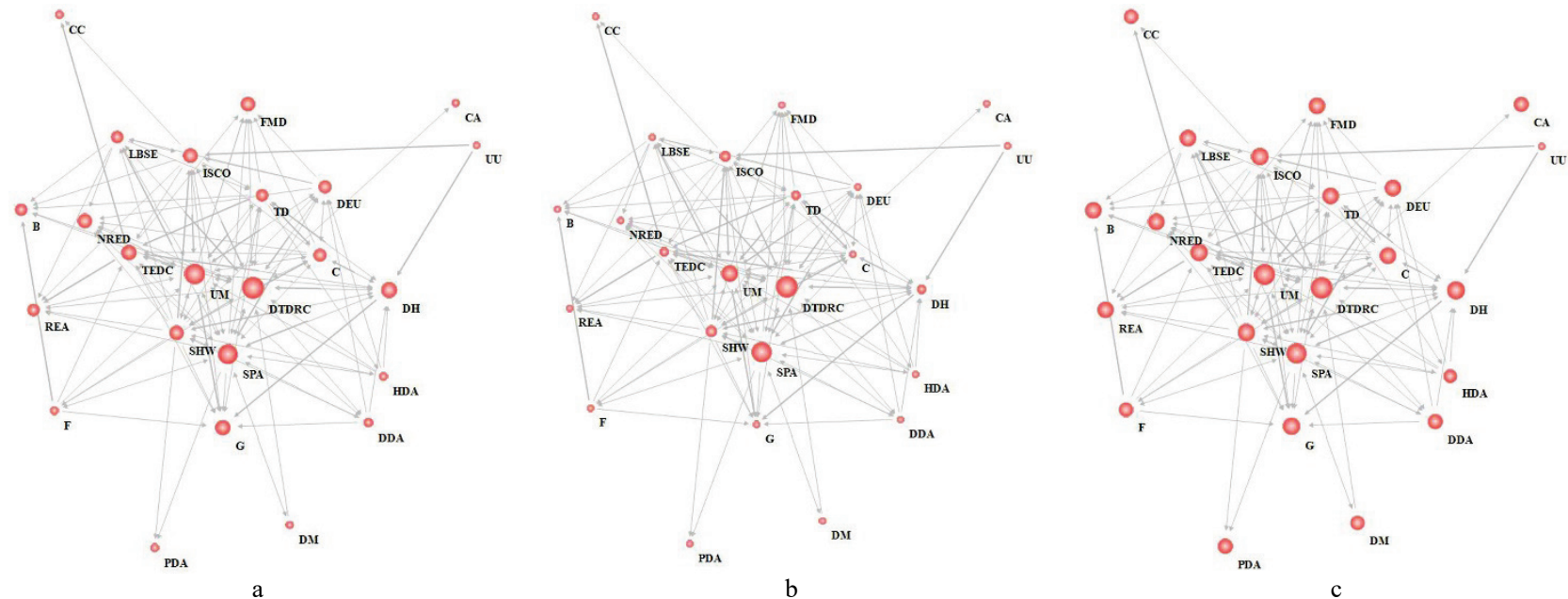

Figure 5 Based on the answers to the first questions, the following graphs for actors and ties between actors were created: (a) Degree network map and degree centrality graph; (b) Betweenness network map and betweenness centrality graph; (c) Closeness network map and closeness centrality graph

Table 9 Maximum and minimum values for the in-out degree, betweenness and in-out closeness centrality of the question "How often do you get the spatial data you need from the organizations within the last year?"

\begin{tabular}{|c|c|c|c|c|c|}
\hline & & Maximum & & Minimum & Std. Dev. \\
\hline \multirow{3}{*}{ In Degree } & Directorate of Title Deed Registry and Cadastre & 0,696 & University of Usak & 0,000 & \multirow{3}{*}{0,188} \\
\hline & Usak Municipality & 0,652 & Chamber of Agriculture & 0,043 & \\
\hline & Special Provincial Administration & 0,609 & Directorate of Museums & 0,043 & \\
\hline \multirow{3}{*}{ Out Degree } & Special Provincial Administration & 0,783 & Chamber of Agriculture & 0,000 & \multirow{3}{*}{0,245} \\
\hline & State Hydraulic Works & 0,696 & Chamber of Commerce & 0,000 & \\
\hline & Usak Municipality & 0,652 & Provincial Directorate of Agriculture & 0,000 & \\
\hline \multirow{3}{*}{ Betweenness } & Directorate of Title Deed Registry and Cadastre & 0,153 & Chamber of Agriculture & 0,000 & \multirow{3}{*}{0,044} \\
\hline & Special Provincial Administration & 0,144 & Chamber of Commerce & 0,000 & \\
\hline & Usak Municipality & 0,101 & Provincial Directorate of Agriculture & 0,000 & \\
\hline \multirow{3}{*}{ In Closeness } & Directorate of Title Deed Registry and Cadastre & 0,704 & University of Usak & 0,000 & \multirow{3}{*}{0,132} \\
\hline & Usak Municipality & 0,671 & Housing Development Administration & 0,335 & \\
\hline & Special Provincial Administration & 0,640 & Directorate of Museums & 0,361 & \\
\hline \multirow{3}{*}{ Out Closeness } & Special Provincial Administration & 0,809 & Chamber of Agriculture & 0,000 & \multirow{3}{*}{0,256} \\
\hline & Directorate of Title Deed Registry and Cadastre & 0,752 & Chamber of Commerce & 0,000 & \\
\hline & Usak Municipality & 0,726 & Courts & 0,000 & \\
\hline
\end{tabular}

Table 10 Density of data sharing potential of the network

\begin{tabular}{|c|c|c|c|c|}
\hline Relationships & Determinations & $\begin{array}{l}\text { The resulting } \\
\text { number of } \\
\text { relations (1) }\end{array}$ & $\begin{array}{l}\text { The overall density of the } \\
\text { network by the number of } \\
\text { relationships }(2)=(1) / 552\end{array}$ & $\begin{array}{l}\text { Level of } \\
\text { realization }\end{array}$ \\
\hline \multirow{5}{*}{ 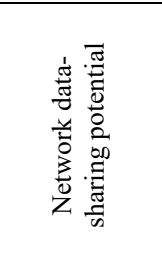 } & Can you have access to the following organizations to collect data? & 290 & 0,525 & Middle \\
\hline & To what extent the organizations provide you the data you need? & 176 & 0,319 & Low \\
\hline & $\begin{array}{l}\text { To which organizations do you provide the data you generate and how } \\
\text { often do you provide? }\end{array}$ & 148 & 0,268 & Low \\
\hline & $\begin{array}{l}\text { Do you know what kind of spatial data the following organizations } \\
\text { generate? }\end{array}$ & 354 & 0,641 & $\begin{array}{l}\text { Above the } \\
\text { middle }\end{array}$ \\
\hline & $\begin{array}{l}\text { How often did you get the spatial data you need from the organizations } \\
\text { within the last year? }\end{array}$ & 156 & 0,283 & Low \\
\hline
\end{tabular}




\subsection{Results for the Roles of Organizations in the Network}

Centrality measures are important to determine the positions and roles or organization in a network. In the social network analysis measures section, five actors are defined for social networks as seen in Table 2. These are: star, gatekeeper, bridge, intermediary and isolated. When we examine the data sharing potentials of organizations in a SDI, organizations that have high degree, betweenness and closeness centrality measures are identified in order to determine these roles.

Star, refers to an actor at a central position in the network. When Degree, betweenness and closeness chart values are considered, organizations that are network stars are DTDRC, SPA and UM. As these organizations also have the highest number of direct ties, they have critical positions in the social network. These organizations are active in the network and play an important role for the network activity.

Gatekeeper, refers to a discrete actor that connects two different groups in a social network but does not belong to either of the groups. When the analyses for the social network structures were reviewed, there were no two groups that are independent of each other and there were no organization that has the gatekeeper role and was isolated from groups.

Bridge, this role is defined as membership to several groups and acting to provide connections with other groups. When the analyses for the social network structures were reviewed, as two or more number of blocks were not available in the social network, no organization assumed the role, bridge.

Intermediary, this role is defined as the actor that acts as the intermediary and controls the flow in the social network It is possible to identify intermediary organizations using betweenness centrality. When betweenness measures are examined, it is possible to observe that DTDRC and SPA can be intermediary organizations. These organizations have high potentials to control data flow among organizations, and act as the intermediary to the shared data in the network. When these organizations leave the network, it is possible that other organization couples' ties can be broken.

\section{CONCLUSION}

This study aimed to show the awareness of the organizations that generate and use spatial data and thus contribute to the on-going planning process for the SDI concept. Relations among public institutions and agencies, local governments that generate spatial data and all industries that work with spatial data were examined for the technical aspects and the interoperability which the organizations have created unintentionally and which do not have defined rules were shown with "social networks". It is possible to say that all these results and evaluations for the city represent the country in general.

The study shows the results and evaluations on the current state of the spatial data sharing; which organizations play an active role; which organizations generate the highest number of spatial data and which organizations use spatial data the most. Thus, this study provided an insight into the organizations that should be prioritized in any regulation and initiative on the spatial data infrastructure (SDI). Furthermore, it is proposed that organizations that are determined to be less active with spatial data in this study can play a more active role with the quantitative and qualitative increase in e-applications under the SDI. The priority goals for SDI are to ensure that the existing operations are carried out in the fastest, costefficient way without resorting to repetitive data generation and with a standard that can be used by every organization. Therefore, a study that shows the present state is important.

Organizations are generally aware of what the others generate as spatial data and what kind of spatial data they use. However, it was possible to understand from the spatial data the organization generates that awareness was only limited to the data related with their operations. The process of asking data from other organizations that involves many levels and much paperwork causes frustration. The logic of interoperable networks is that they are based on flexible structures contrary to the strictly regulated bureaucracy. Flexible structures required by networks facilitate information flow and share, and emphasize the importance of participation and shared responsibility. Therefore it is important to reinforce internal communications of the organizations and to build closer ties with different sections of other organizations based on trust. On the other hand, the fact that the amount of spatial data circulating among organizations is low demonstrates that data is generated repeatedly within organizations, which refers to a situation where no cost and time saving is achieved. Low network density, the fact that the percentage of the requested spatial data provided by other organizations is low demonstrates that organizational needs are not met and organizations generally carry out their operations using their own means. Repetitive data is generated due to the fact that the required spatial data is not provided by other organizations or that organizations do not know that the others have the data they need. As data is repetitively generated, the same data is generated by several organizations leading to economic losses and loss of time. It is important to identify potential users and make a clear distinction between organizations that generate or use data in order to clearly and correctly determine the spatial data that are generated repeatedly. It can be concluded that organizations with low network density have not adopted sharing which is one of the important stages of the SDI. Coordinated generation, update, sharing and use of information local/regional/national and international levels have recently become an important necessity. Sharing culture should be encouraged and widespread in the provincial organizations that are the smallest units in this hierarchy.

\section{REFERENCES}

[1] Dessers, E. (2013). Spatial Data Infrastructures at Work: Analysing the Spatial Enablement of Public Sector Processes. Louvain, Belgium: Leuven University Press.

[2] Sherman, M. (2010). Spatial Statistics and Spatio-Temporal Data: Covariance Functions and Directional Properties. Hobooken, N. J., Wiley. https://doi.org/10.1002/9780470974391

[3] Aleksić, I. R., Gučević, J., \& Sekulić, D. M. (2014). Geodata Management by Developing of National Data Infrastructure 
in The Republic of Serbia. Geodetski Vestnik, 58(4), 756766. https://doi.org/10.15292/geodetski-vestnik.2014.04.756-766

[4] Aleksić, I. R., Kuburić, M., \& Aleksić, L. (2014). Technical Implementation of the National Spatial Data Infrastructure in Serbia. Tehnicki Vjesnik-Technical Gazette, 24(1), 319325.

[5] Van Rheenen, S., Watson, T. J., Alexander, S., \& Hill, M. D. (2015). An Analysis of Spatial Clustering of Stroke Types. In-hospital Mortality, and Reported Risk Factors in Alberta, Canada, Using Geographic Information Systems. The Canadian Journal of Neurological Sciences. Le Journal Canadien Des Sciences Neurologiques, 42(5), 299-309. https://doi.org/10.1080/00221341.2016.1175495

[6] Metoyer, S. \& Bednarz, R. (2017). Spatial Thinking Assists Geographic Thinking: Evidence from a Study Exploring the Effects of Geospatial Technology. Journal of Geography, 116(1), 20-33.

[7] Ticher, P. (2008). Data Protection VS Freedom of Information: Access and Personal Data. Ely, IT Governance Publishing.

[8] Winn, J. K. (2006). Consumer Protection in the Age of the 'Information Economy'. Aldershot, Hants, England, Routledge.

[9] Posey, C., Roberts, T. L., Lowry, P. B., Bennett, R. J., \& Courtney, J. F. (2013). Insiders' Protection of Organizational Information Assets: Development of a Systematics-Based Taxonomy and Theory of Diversity for Protection-Motivated Behaviors. MIS Quarterly, 37(4), 1189-A9. https://doi.org/10.25300/MISQ/2013/37.4.09

[10] Trilles, S., Juan, P., Diaz, L., Arago, P., \& Huerta, J. (2013). Integration of Environmental Models in Spatial Data Infrastructures: A Use Case in Wildfire Risk Prediction. IEEE Journal of Selected Topics in Applied Earth Observations and Remote Sensing, 6(1), 128-138. https://doi.org/10.1109/JSTARS.2012.2236538

[11] Cetl, V., Tóth, K., \& Smits, P. (2012). INSPIRE from the JRC Point of View. Kartografija i geoinformacije, 11(18), 38-55.

[12] Tóth, K. \& Kučas, A. (2016). Spatial information in European agricultural data management. Requirements and interoperability supported by a domain model. Land Use Policy, 57, 64-79. https://doi.org/10.1016/j.landusepol.2016.05.023

[13] Desourdis, R. I. (2009). Achieving Interoperability in Critical it and Communication Systems. Boston: Artech House, Inc.

[14] Monika, M. (2017). Interoperability Cadastral Data in the System Approach. Journal of Ecological Engineering, 18(2), 150-156. https://doi.org/10.12911/22998993/68303

[15] Van Wyk, B. \& Du Toit, A. A. (2016). A Survey of Sustainable Curation in Research Repositories of Higher Education Institutions in Southern Africa. African Journal of Library, Archives \& Information Science, 26(2), 107-116.

[16] Innerebner, M., Costa, A., Chuprikova, E., Monsorno, R., \& Ventura, B. (2017). Organizing earth observation data inside a spatial data infrastructure. Earth Science Informatics, 10(1), 55. https://doi.org/10.1007/s12145-016-0276-0

[17] Tetiana, O. \& Olena, T. (2016). Conceptual approaches to international cooperation between higher education institutions. International Economic Policy, 25(2), 40-58.

[18] Wager, E. \& Kleinert, S. (2012). Review: Cooperation between research institutions and journals on research integrity cases: Guidance from the Committee on Publication Ethics (COPE). Maturitas, 72, 165-169. https://doi.org/10.1016/j.maturitas.2012.03.011

[19] Borgatti, S., Everett, M., \& Freeman, L. (2002). Ucinet for Windows: Software for Social Network Analysis. Analytic Technologies.

[20] Polat, Z. A. \& Alkan, M. (2016). Querying Cadastral Parcel Data Defined by Inspire Uri Model by Using Qr Code:
Turkish Case Study. Sigma: Journal of Engineering \& Natural Sciences / Mühendislik ve Fen Bilimleri Dergisi, 34(1), 57-69.

[21] Uluç, Ç. \& Tecim, V. (2013). A real estate appraisal information system in the process of European Union.

[22] Lingua, A. M., Piras, M., Musci, M. A., Noardo, F., Grasso, N., \& Verda, V. (2016). Study and development of a GIS for fire-fighting activities based on INSPIRE directive. Geomedia, 20(3), 28.

[23] Aleksić, R. I. (2013). INSPIRATION-Spatial Data Infrastructure in the Western Balkans-Country Report SERBIA. The European Union's IPA Programme: Reference $\mathrm{N}^{\circ}$ : 2011/281-381, Project Identification No. EuropeAid /130907/C/SER/ Multi. Publisher: GDiGisdata, Zagreb.

[24] Bernard, C., Villanova-Oliver, M., Gensel, J., \& Le Rubrus, B. (2017). Spatio-Temporal evolutive Data Infrastructure: a Spatial Data Infrastructure for managing data flows of Territorial Statistical Information. International Journal of Digital Earth, 10(3), 257-283. https://doi.org/10.1080/17538947.2016.1222003

[25] Željko, B., Ljerka, R., \& Miljenko, L. (2010). Developing Spatial Data Infrastructure in Croatia - Incorporating National and Regional Approach. Kartografija $i$ Geoinformacije, 9(14), 4-23.

[26] Lianlian, H., Peng, Y., Liping, D., Mingda, Z., \& Lei, H. (2015). Adding Geospatial Data Provenance into SDI-A Service-Oriented Approach. IEEE Journal of Selected Topics in Applied Earth Observations and Remote Sensing, (2), 926,

[27] Kadry, S. \& Al-Taie, M. Z. (2014). Social Network Analysis: An Introduction with an Extensive Implementation to a Large-scale Online Network Using Pajek. Oak Park, IL, Bentham Science Publishers. https://doi.org/10.2174/97816080581811140101

[28] Magsino, S. L. (2009). Applications of Social Network Analysis for Building Community Disaster Resilience: Workshop Summary. Washington, D. C., National Academies Press.

[29] Vicsek, L., Király, G., \& Kónya, H. (2016). Networks in the Social Sciences: Comparing Actor-Network Theory and Social Network Analysis. Corvinus Journal of Sociology \& Social Policy, 7(2), 77. https://doi.org/10.14267/CJSSP.2016.02.04

[30] Cheng, H., Zhou, Y., Huang, X., \& Yu, J. (2012). Clustering large attributed information networks: an efficient incremental computing approach. Data Mining \& Knowledge Discovery, 25(3), 450. https://doi.org/10.1007/s10618-012-0263-0

[31] McCulloh, I., Johnson, A. N., \& Armstrong, H. (2013). Social Network Analysis with Applications. Hoboken, New Jersey: Wiley.

[32] Barnhill, J. P. (2014). Social network analysis (SNA). Salem Press Encyclopedia.

[33] Freeman, L. C. (1979). Centrality in social networks: Conceptual clarification. Social Networks, 1(3), 215-239. https://doi.org/10.1016/0378-8733(78)90021-7

[34] Sabidussi, G. (1966). The centrality index of a graph. Psychometrika, 31(4), 581-603. https://doi.org/10.1007/BF02289527

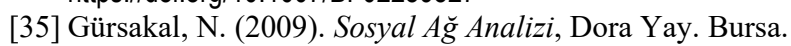

[36] Laumann, E. O., Marsden, P. V., Prensky, D., Burt, R. S., \& Minor, M. J. (1983). Applied network analysis, 18-34.

[37] Seevers, M. T., Johnson, B. R., \& Darnold, T. C. (2015). Social networks in the classroom: personality factors as antecedents of student social capital. American Journal of Business Education, 8(3), 193. https://doi.org/10.19030/ajbe.v8i3.9281 


\section{Contact information:}

Fatih TAKTAK, PhD

Usak University,

Faculty of Engineering,

Department of Geomatics Engineering,

64200,1 Eylul campus, Usak, Turkey

E-mail: fatih.taktak@usak.edu.tr

Hulya DEMIR, Prof. Dr.

Yildiz Teknical University,

Faculty of Civil Engineering,

Department of Geomatics Engineering,

34220, Davutpasa campus, Istanbul, Turkey

E-mail: hudemir@yildiz.edu.tr 